\title{
Result Summary for the Area 5 Radioactive Waste Management Site Performance Assessment Model Version 4.110
}

Results for Version 4.110 of the Area 5 Radioactive Waste Management Site (RWMS) performance assessment (PA) model are summarized. Version 4.110 includes the fiscal year (FY) 2010 inventory estimate, including a future inventory estimate. Analyses are summarized in Table 1.

Table 1. Summary of analyses

\begin{tabular}{|c|c|c|}
\hline Inventory & Analysis & Realizations \\
\hline Post-1988, Future & Member of Public, Intruder, Radon Flux & 5,000 \\
\hline Pre-, Post-1988, and Future & Member of Public & 5,000 \\
\hline
\end{tabular}

Version 4.110 was implemented in GoldSim 10.11(SP4). The following changes have been implemented since the last baseline model, Version 4.105:

- Updated the inventory and disposal unit configurations with data through the end of FY 2010.

- Implemented Federal Guidance Report 13 Supplemental CD dose conversion factors (U.S. Environmental Protection Agency, 1999).

\section{Performance Assessment Results}

Version 4.110 PA results comply with air pathway and all-pathways annual total effective dose (TED) performance objectives (Tables 2 and 3, Figures 1 and 2). Air pathways results decrease moderately for all scenarios. The time of the maximum for the air pathway open rangeland scenario shifts from 1,000 to 100 years (y). All-pathways annual TED increases for all scenarios except the resident scenario.

Table 2. Member of public annual TED through the air pathway

\begin{tabular}{|c|c|c|c|}
\hline Exposure Scenario & Mean $(\mathrm{mSv})$ & $\begin{array}{c}95^{\text {th }} \text { Percentile } \\
(\mathrm{mSv})\end{array}$ & $\begin{array}{c}\text { Time of } \\
\text { Maximum }\end{array}$ \\
\hline Transient Visitor & $4.8 \mathrm{E}-5$ & $1.9 \mathrm{E}-4$ & 1,000 years \\
\hline Resident & $1.3 \mathrm{E}-4$ & $5.3 \mathrm{E}-4$ & 1,000 years \\
\hline Resident Farmer & $1.8 \mathrm{E}-4$ & $6.9 \mathrm{E}-4$ & 1,000 years \\
\hline Open Rangeland (Cane Spring) & $6.5 \mathrm{E}-9$ & NA & 100 years \\
\hline Open Rangeland (NNSS Boundary) & $8.9 \mathrm{E}-8$ & NA & 100 years \\
\hline
\end{tabular}

NA - not available, insufficient non-zero values to calculate $95^{\text {th }}$ percentile

NNSS - Nevada National Security Site

The maximum member of public all-pathways dose occurs at 1,000 y for the resident farmer scenario. The resident farmer dose was predominately due to technitium-99 (Tc-99) (82 percent) and lead-210 (Pb-210) (13 percent). Pb-210 present at 1,000 y is produced predominately by radioactive decay of uranium-234 (U-234) present at the time of disposal. 
Table 3. Member of public annual TED through all-pathways

\begin{tabular}{|c|c|c|c|}
\hline Exposure Scenario & Mean $(\mathrm{mSv})$ & $\begin{array}{c}95^{\text {th }} \text { Percentile } \\
(\mathrm{mSv})\end{array}$ & $\begin{array}{c}\text { Time of } \\
\text { Maximum }\end{array}$ \\
\hline Transient Visitor & $3.8 \mathrm{E}-3$ & $8.4 \mathrm{E}-3$ & 1,000 years \\
\hline Resident & $6.6 \mathrm{E}-4$ & $2.4 \mathrm{E}-3$ & 1,000 years \\
\hline Resident Farmer & $1.7 \mathrm{E}-2$ & $5.3 \mathrm{E}-2$ & 1,000 years \\
\hline Open Rangeland (Cane Spring) & $2.8 \mathrm{E}-3$ & NA & 100 years \\
\hline Open Rangeland (NNSS Boundary) & $3.0 \mathrm{E}-3$ & NA & 100 years \\
\hline
\end{tabular}

All results for the postdrilling and intruder-agriculture scenarios comply with the performance objectives (Tables 4 and 5, Figures 3 and 4). The postdrilling intruder results are similar to Version 4.105 results. The intruder-agriculture results are similar to Version 4.105, except for the Pit 6 Radium Disposal Unit (RaDU). The intruder-agriculture result for the Shallow Land Burial (SLB) disposal units is a significant fraction of the performance objective and exceeds the performance objective at the $95^{\text {th }}$ percentile. The intruder-agriculture dose is due predominantly to Tc-99 (75 percent) and U-238 (9.5 percent).

Table 4. Postdrilling intruder TED weighted by the probability of occurrence

\begin{tabular}{|c|c|c|c|}
\hline Disposal Unit & Mean $(\mathrm{mSv})$ & $\begin{array}{c}95^{\text {th }} \text { Percentile } \\
(\mathrm{mSv})\end{array}$ & $\begin{array}{c}\text { Time of } \\
\text { Maximum }\end{array}$ \\
\hline (SLB & $5.6 \mathrm{E}-3$ & $1.8 \mathrm{E}-2$ & 1,000 years \\
\hline Pit 6 RaDU & $7.4 \mathrm{E}-4$ & $2.0 \mathrm{E}-3$ & 1,000 years \\
\hline Pit 13 RaDU & $1.4 \mathrm{E}-3$ & $3.1 \mathrm{E}-3$ & 1,000 years \\
\hline Greater Confinement Disposal (GCD) & $2.9 \mathrm{E}-7$ & $9.7 \mathrm{E}-7$ & 1,000 years \\
\hline
\end{tabular}

Table 5. Intruder intruder-agriculture TED weighted by the probability of occurrence

\begin{tabular}{|c|c|c|c|}
\hline Disposal Unit & Mean $(\mathrm{mSv})$ & $\begin{array}{c}95^{\text {th }} \text { Percentile } \\
(\mathrm{mSv})\end{array}$ & $\begin{array}{c}\text { Time of } \\
\text { Maximum }\end{array}$ \\
\hline SLB & 0.39 & 1.3 & 1,000 years \\
\hline Pit 6 RaDU & $1.4 \mathrm{E}-3$ & $4.2 \mathrm{E}-3$ & 1,000 years \\
\hline Pit 13 RaDU & $7.3 \mathrm{E}-4$ & $2.6 \mathrm{E}-3$ & 1,000 years \\
\hline GCD & $3.9 \mathrm{E}-10$ & NA & 100 years \\
\hline
\end{tabular}

$\mathrm{NA}$ - not available, insufficient non-zero values to calculate $95^{\text {th }}$ percentile

The acute intruder scenario results comply with all performance objectives (Tables 6 and 7, Figures 5 and 6). The acute construction result for the SLB disposal units decreases significantly with this version. The maximum acute intruder dose occurs at 1,000 y for the SLB disposal units under the acute construction scenario. The acute intruder dose is caused by multiple radionuclides including U-238 (31 percent), Th-229 (28 percent), plutonium-239 (8.6 percent), U-233 (7.8 percent), and U-234 (6.7 percent).

Table 6. Acute drilling intruder TED

\begin{tabular}{|c|c|c|c|}
\hline Disposal Unit & Mean $(\mathrm{mSv})$ & $\begin{array}{c}95^{\text {th }} \text { Percentile } \\
(\mathrm{mSv})\end{array}$ & $\begin{array}{c}\text { Time of } \\
\text { Maximum }\end{array}$ \\
\hline Shallow Land Burial (SLB) & $2.1 \mathrm{E}-3$ & $4.1 \mathrm{E}-3$ & 1,000 years \\
\hline Pit 6 RaDU & 0.028 & 0.052 & 1,000 years \\
\hline Pit 13 RaDU & 0.026 & 0.034 & 1,000 years \\
\hline GCD & 0.016 & 0.041 & 1,000 years \\
\hline
\end{tabular}


Table 7. Acute construction intruder TED

\begin{tabular}{|c|c|c|c|}
\hline Disposal Unit & Mean $(\mathrm{mSv})$ & $\begin{array}{c}95^{\text {th }} \text { Percentile } \\
(\mathrm{mSv})\end{array}$ & $\begin{array}{c}\text { Time of } \\
\text { Maximum }\end{array}$ \\
\hline SLB & 1.1 & 2.1 & 1,000 years \\
\hline Pit 6 RaDU & 0.15 & 0.28 & 1,000 years \\
\hline Pit 13 RaDU & 0.060 & 0.19 & 1,000 years \\
\hline GCD & $2.7 \mathrm{E}-6$ & NA & 100 years \\
\hline
\end{tabular}

All results for radon-222 (Rn-222) flux density comply with the performance objective (Table 8, Figure 7). The mean Pit $13 \mathrm{RaDU}$ flux density is close to the $0.74 \mathrm{~Bq} \mathrm{~m}^{-2} \mathrm{~s}^{-1}$ limit.

Table 8. Rn-222 flux density results

\begin{tabular}{|c|c|c|c|}
\hline Disposal Unit & Mean $\left(\mathrm{Bq} \mathrm{m}^{-2} \mathrm{~s}^{-1}\right)$ & $\begin{array}{c}95^{\text {th }} \text { Percentile } \\
\left(\mathrm{Bq} \mathrm{m}^{-2} \mathrm{~s}^{-1}\right)\end{array}$ & Time of Maximum \\
\hline All & 0.13 & 0.27 & 1,000 years \\
\hline SLB & 0.12 & 0.26 & 1,000 years \\
\hline Pit 6 RaDU & 0.055 & 0.10 & 1,000 years \\
\hline Pit 13 RaDU & 0.69 & 2.0 & 1,000 years \\
\hline GCD & $1.2 \mathrm{E}-8$ & $3.4 \mathrm{E}-8$ & 1,000 years \\
\hline
\end{tabular}

The composite analysis results are less than the $0.3 \mathrm{mSv}$ dose constraint (Table 9).

Table 9. Composite analysis annual TED results

\begin{tabular}{|c|c|c|c|}
\hline Disposal Unit & Mean $(\mathrm{mSv})$ & $95^{\text {th }}$ Percentile $(\mathrm{mSv})$ & Time of Maximum \\
\hline All & $8.9 \mathrm{E}-4$ & $3.0 \mathrm{E}-3$ & 1,000 years \\
\hline
\end{tabular}

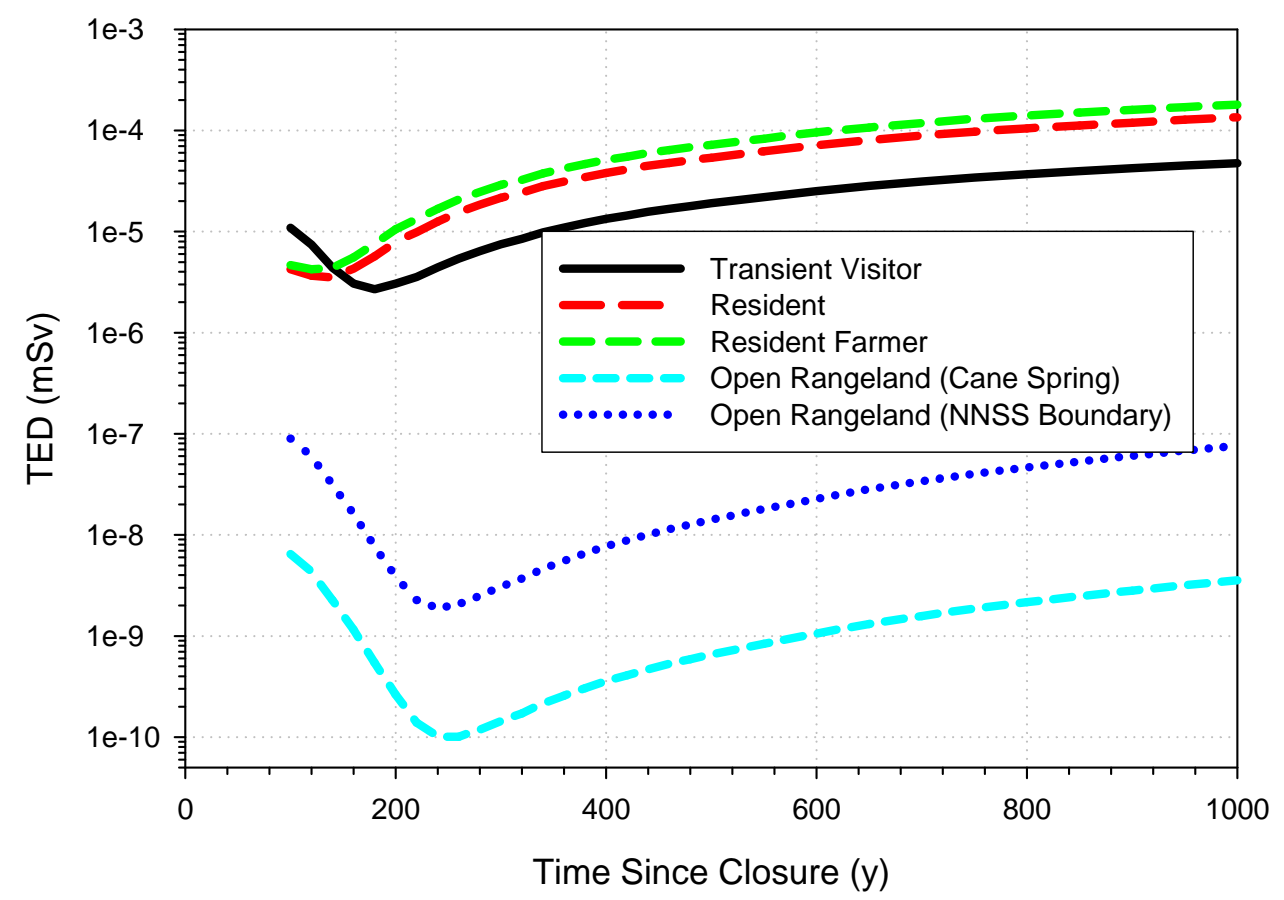

Figure 1. Mean member of public TED time history for the air pathway 


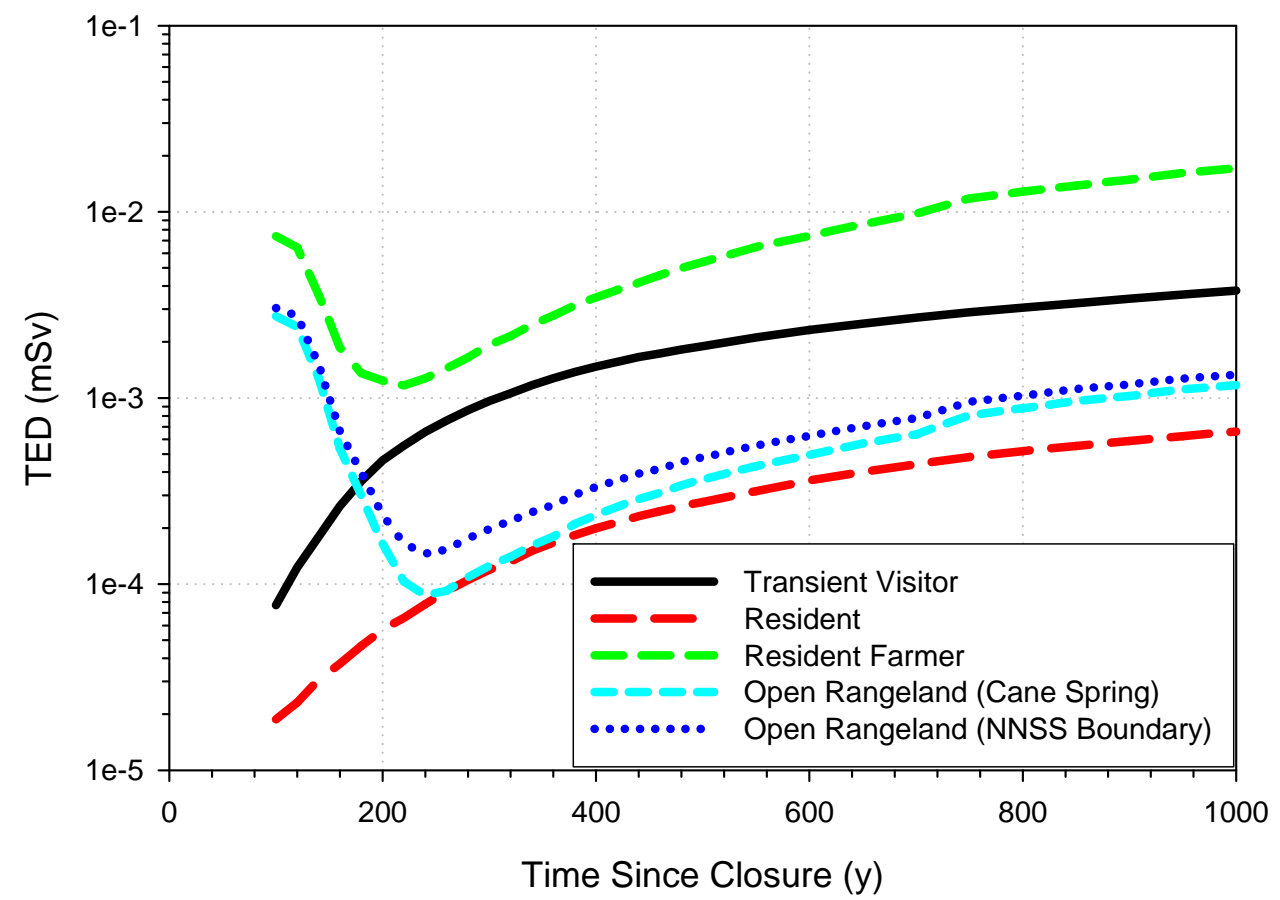

Figure 2. Mean member of public TED time history for all-pathways

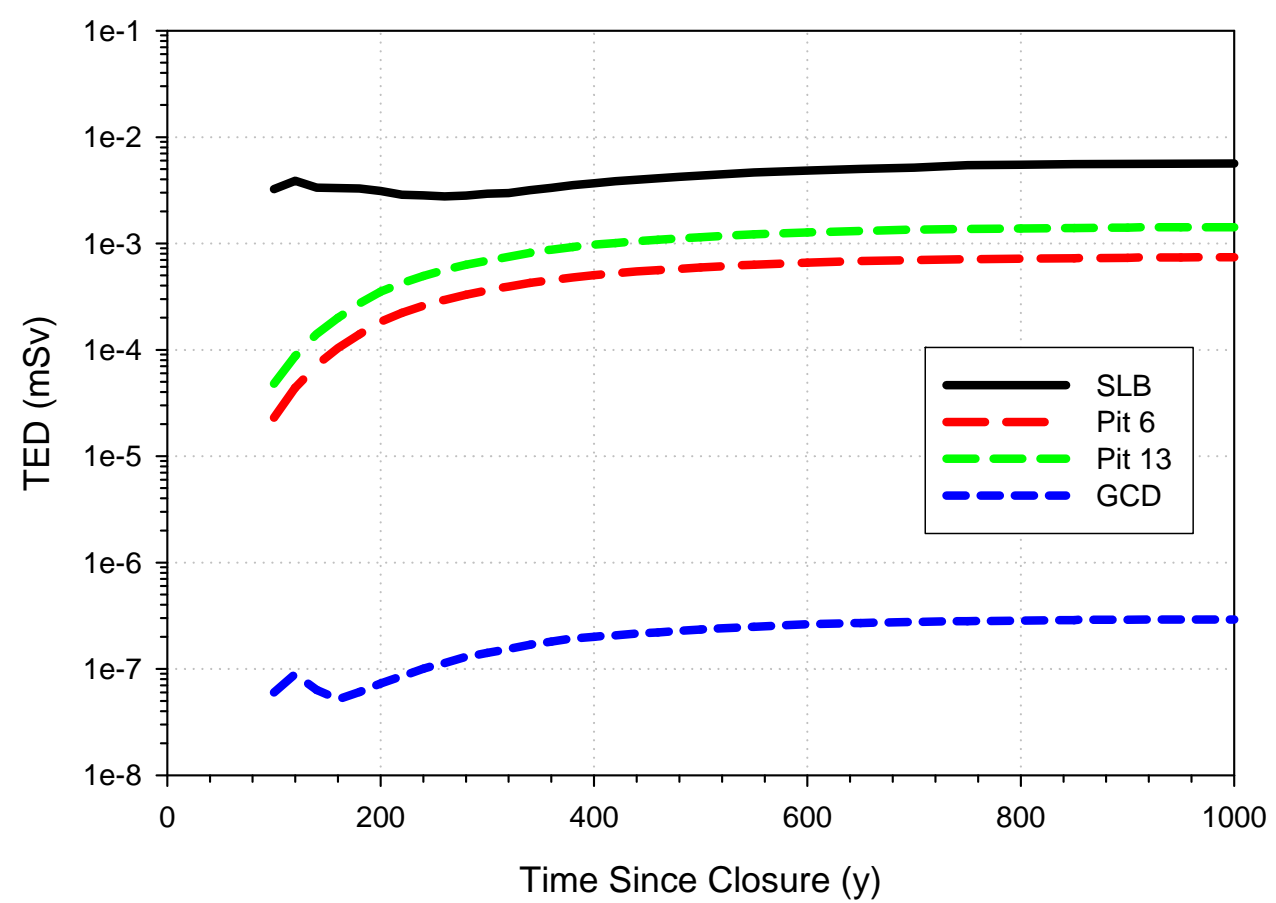

Figure 3. Mean intruder TED time history for the postdrilling intruder scenario 


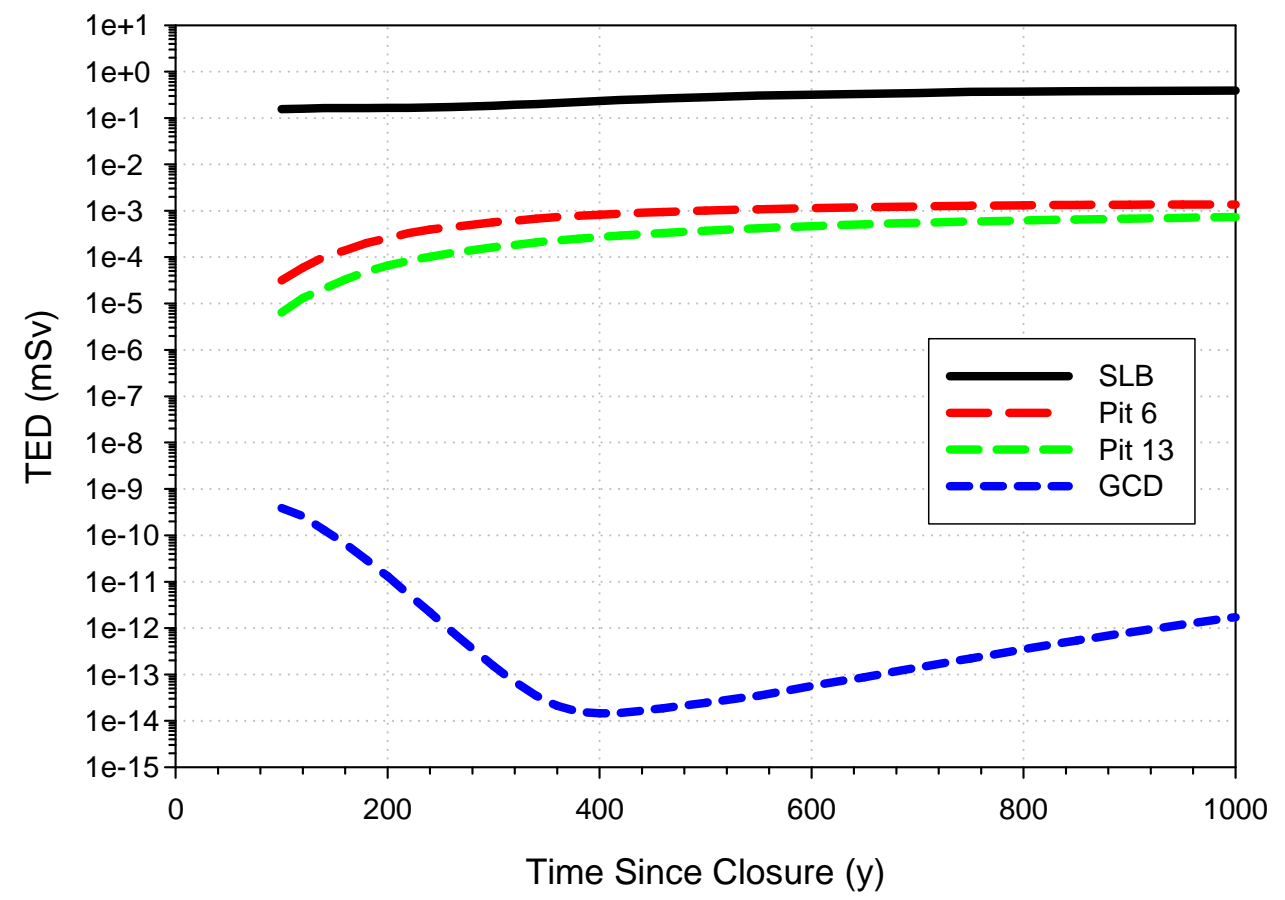

Figure 4. Mean intruder TED time history for the intruder-agriculture scenario

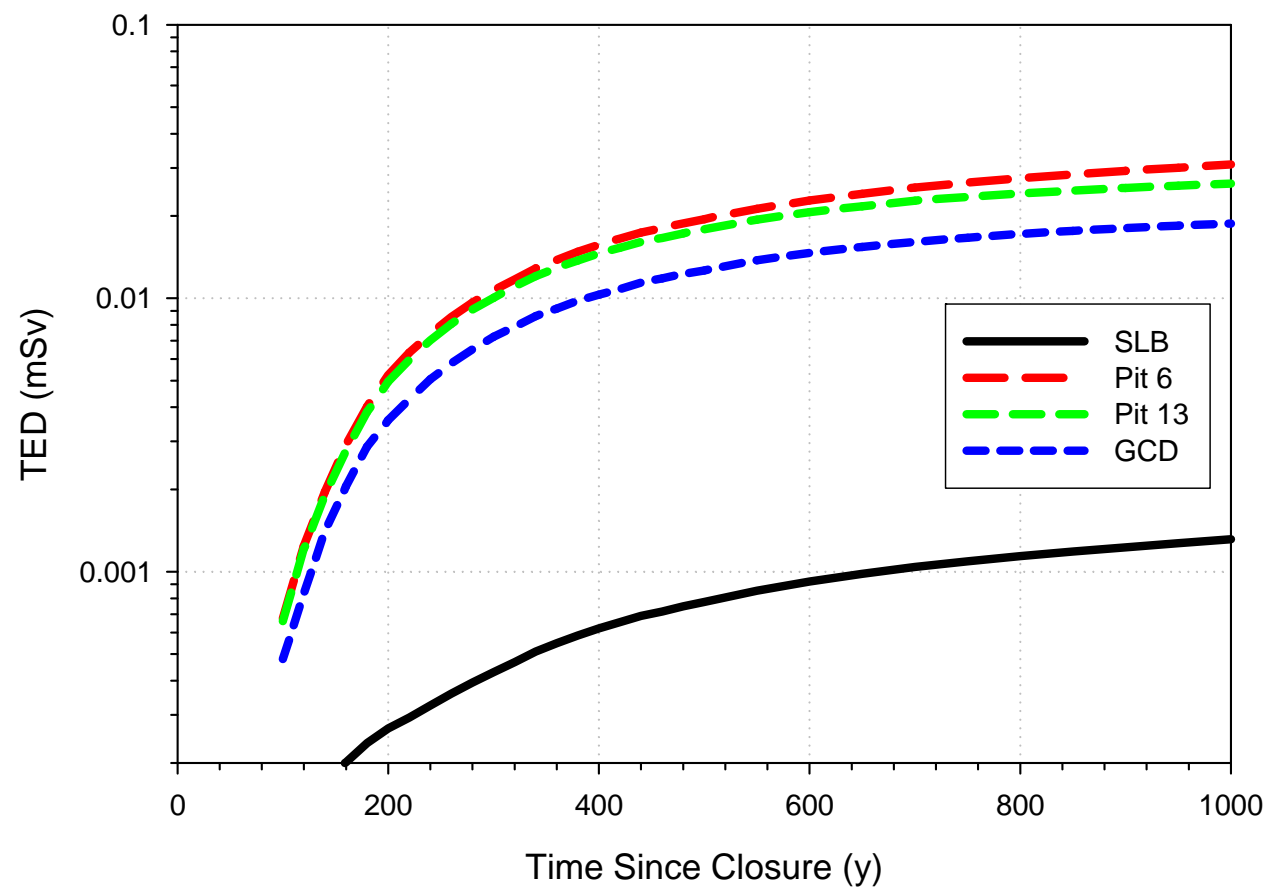

Figure 5. Mean intruder TED time history for the acute drilling scenario 


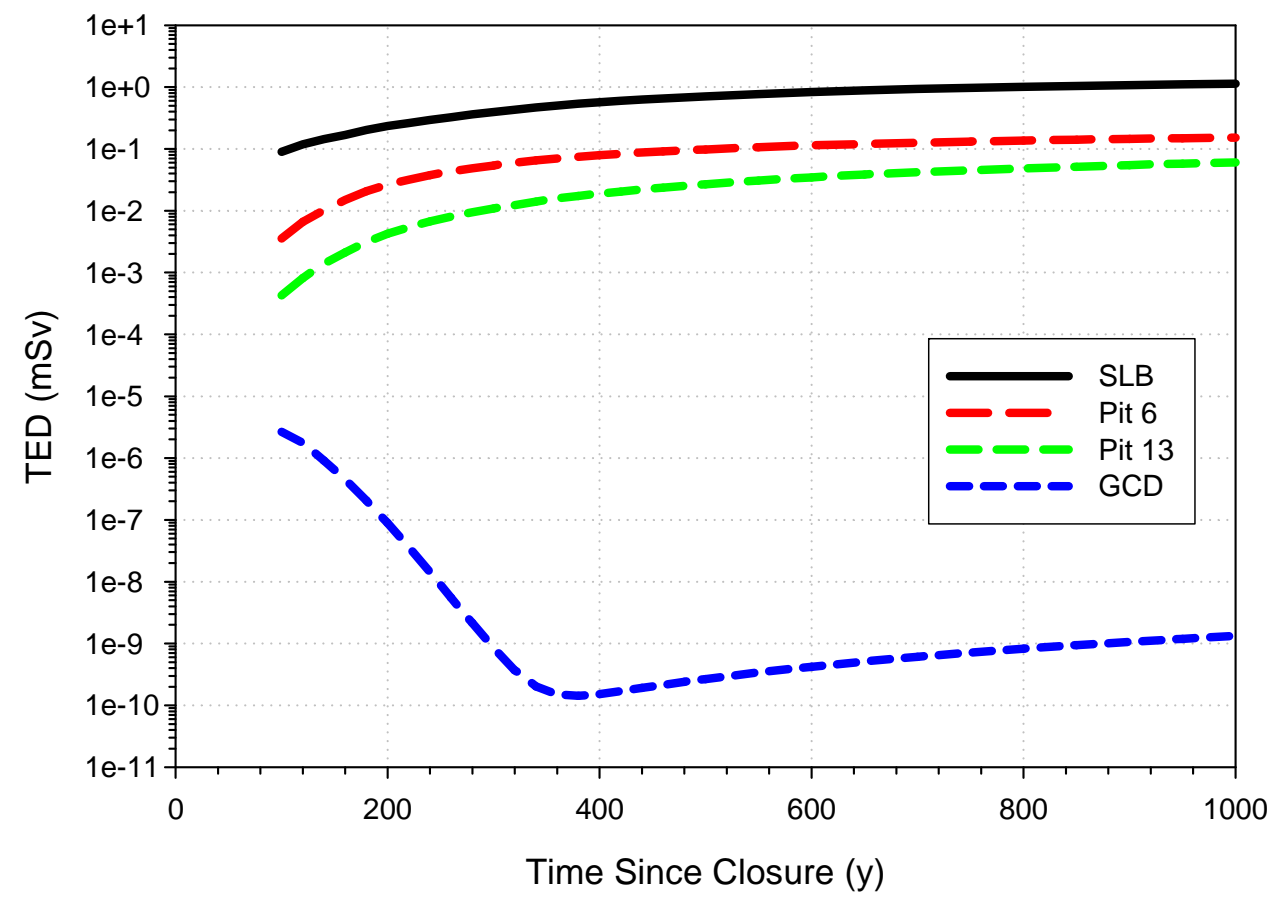

Figure 6. Mean intruder TED time history for the acute construction scenario

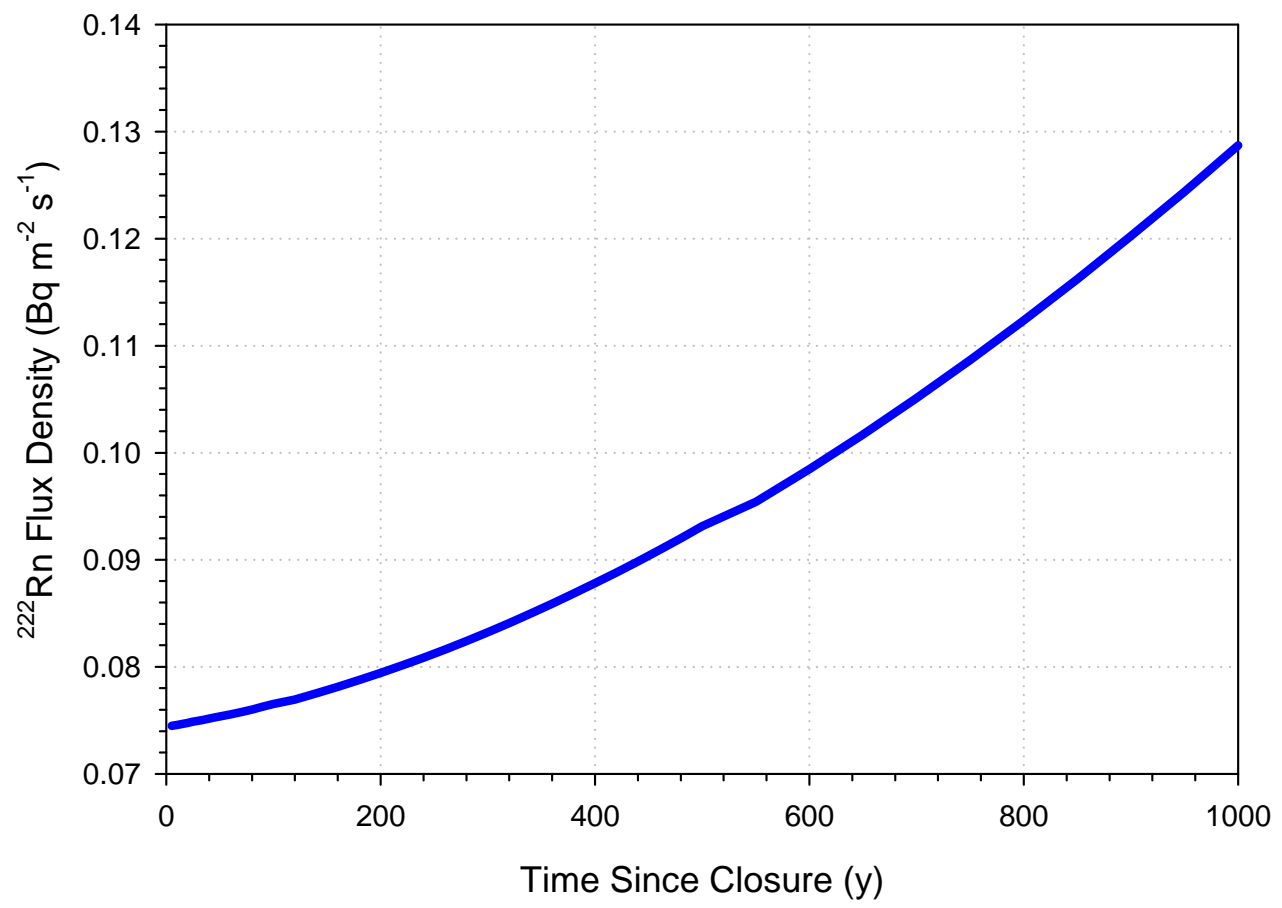

Figure 7. Mean Rn-222 flux density averaged over all disposal units 


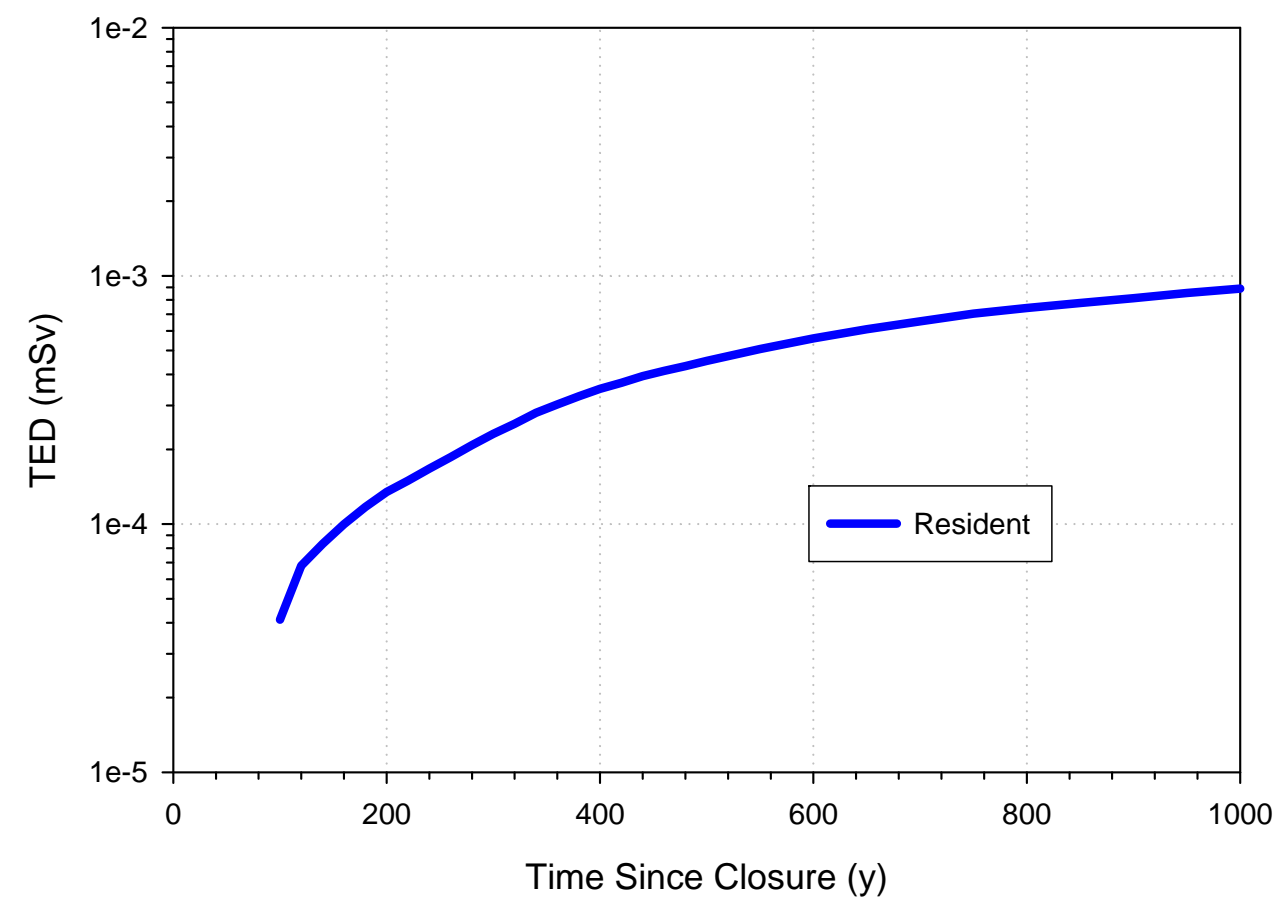

Figure 8. Mean composite analysis TED time history

\section{References}

U.S. Environmental Protection Agency, 1999. Cancer Risk Coefficients for

Environmental Exposure to Radionuclides. Washington, D.C.:

U.S. Environmental Protection Agency, EPA-402-R-99-001, Supplemental CD.

Reference herein to any specific commercial product, process, or service by trade name, trademark, manufacturer, or otherwise, does not necessarily constitute or imply its endorsement, recommendation, or favoring by the U.S. Government or any agency thereof. 